Baseline

\title{
Assessment of nutrient and heavy metal contamination in the seawater and sediment of Yalujiang Estuary
}

\author{
Hongjun $\mathrm{Li}^{\mathrm{a}}$, Lin Lin ${ }^{\mathrm{b}}$, Sheng $\mathrm{Ye}^{\mathrm{a}}$, Hongbo $\mathrm{Li}^{\mathrm{a}}$, Jingfeng Fan ${ }^{\mathrm{a}, *}$ \\ a Marine Ecology Department, National Marine Environmental Monitoring Center, Dalian 116023, China \\ ${ }^{\mathrm{b}}$ Research Center for Eco-Environmental Sciences, Chinese Academy of Sciences, Beijing 100085, China
}

\section{A R T I C L E I N F O}

\section{Article history:}

Received 9 November 2016

Received in revised form 21 January 2017

Accepted 27 January 2017

Available online 6 February 2017

\section{Keywords:}

Yalujiang Estuary

Nutrient

Heavy metal

Seawater

Sediment

\begin{abstract}
A B S T R A C T
Yalujiang River is a famous border river between China and North Korea. In this study, 22 sample sites (seawater and sediments) were investigated to determine the concentrations of nutrients (dissolved inorganic nitrogen and soluble reactive phosphorus) and trace elements ( $\mathrm{Hg}, \mathrm{As}, \mathrm{Pb}, \mathrm{Cu}, \mathrm{Cd}, \mathrm{Cr}$, and $\mathrm{Zn}$ ) during the flood season (August). Generally, the concentration of nutrients were higher in the entrance of the estuary than that in the downstream region and the trophic index ranged from moderate to high production, indicating a potential eutrophication risk. With the exception of $\mathrm{Cd}$, the mean concentrations of most metals attained the first level of seawater quality. Sediment pollution assessment was undertaken using contamination factor $(C F)$ and geoaccumulation index $\left(I_{g e o}\right)$. The $C F$ values of the seven trace elements were in the following order: $\mathrm{Cd}>\mathrm{Hg}>\mathrm{Pb}>\mathrm{As}>\mathrm{Cu}>\mathrm{Zn}>\mathrm{Cr}$. Both $\mathrm{CF}$ and $I_{\text {geo }}$ values indicated the elevated $\mathrm{Cd}$ and $\mathrm{Hg}$ concentrations in the region. Cluster analysis indicated that the sources of $\mathrm{Cu}, \mathrm{Cd}, \mathrm{Cr}$, and $\mathrm{Zn}$ were mainly derived from copper mine and coastal industrial effluents, whereas $\mathrm{Pb}, \mathrm{Hg}$, and As were mainly from vehicle emissions and oil combustion. This study could provide a basis for the sustainable management of the marine ecosystem in this region.
\end{abstract}

(C) 2017 Elsevier Ltd. All rights reserved.
As the confluence area of land runoff and seawater, an estuary transports terrestrial matter to the sea. With the rapid economic development of coastal, estuaries receive substantial amounts of anthropogenic inputs from both point and non-point upstream sources of pollution from industrialization and urbanization activities, and ecological problems have become severe as a result. Consequently, the estuarine ecosystem is one of the most heavily used and globally threatened natural systems (Lotze et al., 2006; Liu et al., 2016a, b). Estuaries often act as nurseries to numerous forms of aquatic life; thus, estuaries are important to aquaculture and fisheries. The intertidal areas of estuaries attract a variety of birds, and these zones are often globally important sites for migratory species. Thus, assessing the contamination in estuaries and its biological influence is crucial.

Heavy metal pollution in the marine environment has received global attention because of the ubiquity, difficult degradation, and easy accumulation of heavy metal pollutants. In estuarine and coastal regions, sediments have been regarded as both carriers and sinks of various contaminants originating from industrial and agricultural processes (Gan et al., 2013; Yang et al., 2012), As a result, sediment contamination is recognized as a major source of marine ecosystem health stress (Chapman and Wang, 2001). Sediments release more heavy metals into the seawater when local environmental conditions (e.g., salinity, $\mathrm{pH}$, and redox

\footnotetext{
* Corresponding author.

E-mail address: jffan@nmemc.org.cn (J. Fan).
}

potential) change (Valdés et al., 2005; Hill et al., 2013). Consequently, the transfer of metals from sediment to water columns and the subsequent bioaccumulation along the food chain are detrimental to the marine environment and public health (Pan and Wang, 2012; Zhang et al., 2012).

Yalujiang Estuary is located in the Northern Yellow Sea, Liaoning Province, China. This estuary is known for being the boundary river between China and North Korea. Yalujiang River originates from Tianchi Lake in Changbaishan Mountain and flows a distance of approximately $790 \mathrm{~km}$ from northeast to southwest through Jilin Province and Liaoning Province. This river supplies the most important sources of drinking water for the surrounding cities. With the rapid urbanization and industrialization in recent years, Yalujiang River suffers from industrial, agricultural, and domestic pollution, which results in potential ecological risks (Gao et al., 2008). Some industrial enterprises (e.g., automobile, papermaking, printing, and textile) are concentrated in the cities of Dandong and Donggang. Substantial amounts of industrial effluents have been taken to the sea by the river, particularly during the flood season. The average water discharge is $3.02 \times 10^{8} \mathrm{~m}^{3} / \mathrm{a}$, of which $70 \%-80 \%$ occurs during the flood season. However, only few pollution investigations have been conducted in Yalujiang Estuary (Wu et al., 2003; Gao et al., 2008; Cheng et al., 2011); as a result, the understanding of the influence of human activities on the marine ecosystem in this region is limited. In the current study, the spatial distribution of heavy metals during the flood season in Yalujiang Estuary is determined, and the 
sources of these pollutants are identified to provide basic information for future pollution monitoring and environmental management.

Seawater and sediment samples for metal analysis were collected from 22 sites in Yalujiang Estuary during the flood season (August 2016) (Fig. 1). The surface seawater samples were collected from $0.5 \mathrm{~m}$ below the surface at each site with 5 L Niskin bottles. The surface sediment samples (top $5 \mathrm{~cm}$ of the surface) were obtained using a van Veen collector $\left(0.05 \mathrm{~m}^{2}\right)$. The bulk sediment samples were divided into three subsamples for the determinations of trace metals, total organic carbon (TOC), and grain size. The seawater salinity and temperature were measured in situ with a multiparameter sensor (YSI6600), and the $\mathrm{pH}$ values were determined with a $\mathrm{pH}$ meter. The seawater for dissolved oxygen (DO) analysis was collected with a tube reaching the bottom of the bottle until the water overflowed. Suspended particulate material samples were filtered through pre-weighted Whatman $\mathrm{GF} / \mathrm{F}$ fiber filters $(25 \mathrm{~mm})$. The samples for metal determination were immediately filtered through Whatman GF/F fiber filters $(0.45 \mathrm{~mm})$, acidified with $10 \% \mathrm{HNO}_{3}$, placed in an icebox, and then transported to the laboratory.

The concentrations of $\mathrm{NO}_{3}, \mathrm{NO}_{2}, \mathrm{NH}_{4}$, and $\mathrm{PO}_{4}$ in seawater were determined following to the methods described by Grasshoff et al. (1983). DO was determined using the Winkler titration method. Chlorophyll- $a$ (Chla) was determined by filtering $100-200 \mathrm{~mL}$ of seawater through a GF/F fiber filter with a cascading filtering device under a low vacuum pressure. After extraction with 90\% acetone, Chla was determined using a Turner Designs fluorometer (TD Trilogy). The concentrations of the dissolved heavy metals were determined by inductively coupled plasma mass spectrometry (ICP-MS, Thermo X series) for $\mathrm{Cd}, \mathrm{Pb}, \mathrm{Zn}, \mathrm{Cu}$, and $\mathrm{Cr}$, whereas the contents of $\mathrm{Hg}$ and As were determined using an atomic fluorescence spectrometer (AFS-920).

The grain sizes of the sediment samples were determined using a Mastersizer 2000 laser particle size analyzer (Malvern, UK). The samples were divided into four fractions according to particle size: clay $(<2 \mu \mathrm{M})$, silt $(2-40 \mu \mathrm{M})$, fine sand $(40-200 \mu \mathrm{M})$, and coarse sand

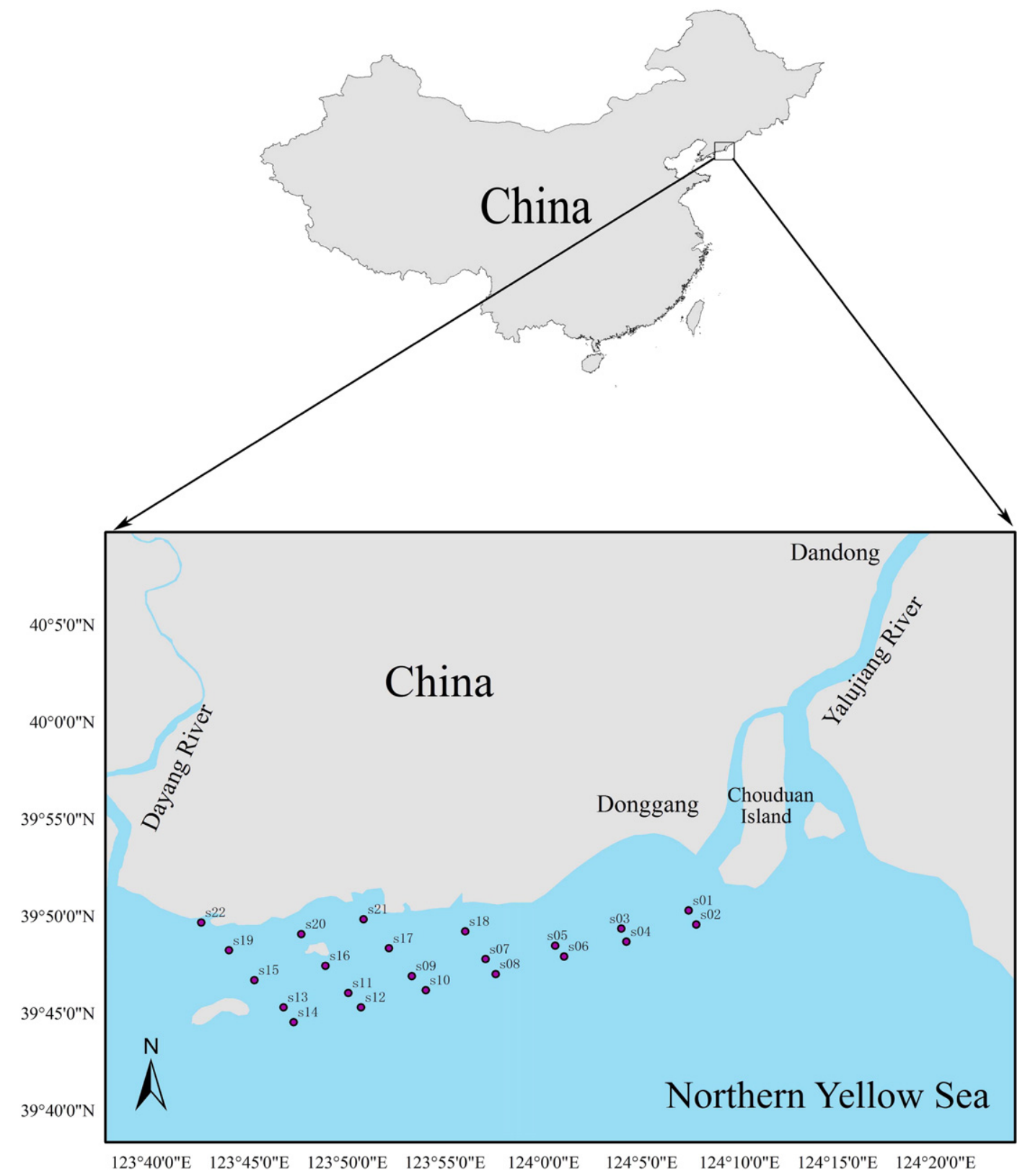

Fig. 1. Location map of sample sites in Yalujiang Estuary. 
(>200 $\mu \mathrm{M}$ ) (Ip et al., 2007). Approximately $20 \mathrm{~g}$ of sediment samples for element analysis were oven-dried $\left(<60^{\circ} \mathrm{C}\right)$ and then ground to powder $(<63 \mu \mathrm{m})$. Approximately $0.2 \mathrm{~g}$ of powdered samples were totally digested in a Teflon vessel with a mixed solution of $\mathrm{HNO}_{3}+\mathrm{HCl}+\mathrm{HF}$ (5:4:1) on a heating plate and heated $\left(<150{ }^{\circ} \mathrm{C}\right)$ to dryness. Afterward, the residue was extracted with $\mathrm{HNO}_{3}$ and diluted to a specific volume. The TOC was measured with an elemental analyzer.

The environmental data of seawater and sediment were analyzed using SPSS 18.0. Pearson correlation analysis was employed to test the relationship among sediment grain size, TOC, sulfide, and trace elements. Cluster analysis (CA) was performed to determine the analyzed parameters and their possible sources (natural or anthropogenic). A hierarchical CA was performed using the hclust function in the $\mathrm{R}$ package pvclust (Suzuki and Shimodaira, 2006), which automatically computes the $p$-value (AU and BP types) for all clusters of the original data.

Eutrophication in marine ecosystems has become a deleterious environmental problem worldwide. In this study, the ecological risks of nitrogen and phosphorus were assessed by the trophic index (TRIX) (Vollenweider et al., 1998):

$$
\text { TRIX }=\frac{\log (\mathrm{Chl} a \times[\% \mathrm{DO}] \times \mathrm{DIN} \times \mathrm{SRP})+1.5}{1.2} .
$$

Chla, DIN, and SRP are the concentrations of Chla $\left(\mathrm{mg} / \mathrm{m}^{3}\right)$, dissolved inorganic nitrogen $\left(\mathrm{mg} / \mathrm{m}^{3}\right)$, and soluble reactive phosphorus $\left(\mathrm{mg} / \mathrm{m}^{3}\right)$, respectively; \%DO is the absolute value of the oxygen saturation deviation $(|100-\% \mathrm{DO}|)$. TRIX is classified into four levels: low production (TRIX $<4)$, moderate production $(4<$ TRIX $<5$ ), between moderate and high production $(5<$ TRIX $<6$ ), and high production (TRIX $>6$ ).

The eutrophication risk of the nutrients ranged from moderate to high production in Yalujiang Estuary (Fig. 2), indicating that the overall condition in the study area was eutrophic. Generally, the worst water quality conditions (in trophic terms) were found at the upper estuary sites (S1, S2, S3, and S4), which were exposed to the highest influence of anthropogenic activities, while better water conditions were detected in the downstream regions (S13-S22). These results indicated that industrial, agricultural, and urban effluent inputs resulted in the elevated nutrient levels in the study area, and such levels are conducive to phytoplankton growth.

The dissolved heavy metal concentrations and other environmental factors in seawater are listed in the Supplement Table S1. The concentrations of $\mathrm{Cu}, \mathrm{Pb}, \mathrm{Zn}, \mathrm{Cr}, \mathrm{As}, \mathrm{Cd}$, and $\mathrm{Hg}$ were $2.86 \pm 0.81,0.68 \pm$ $0.34,14.93 \pm 3.05,0.13 \pm 0.13,1.80 \pm 0.15,1.18 \pm 0.14$, and
$0.029 \pm 0.013 \mu \mathrm{g} / \mathrm{L}$ (Table 1 ), respectively, which are ranked following the order of $\mathrm{Zn}>\mathrm{Cu}>\mathrm{As}>\mathrm{Cd}>\mathrm{Pb}>\mathrm{Cr}>\mathrm{Hg}$. Table 1 provides a comparison of the concentrations of trace elements in some typical regions in China and those in the study area. The concentrations of trace elements in Yalujiang Estuary were higher than those in the Northern Yellow Sea, particularly for $\mathrm{Cr}, \mathrm{Zn}$, and $\mathrm{Hg}$, indicating that the riverine input carried metal pollutants. However, the metal concentrations in Yalujiang Estuary were lower than those in Jinzhou Bay and Tianjin Bay, which are two inner bays of the Bohai Sea. With the exception of $\mathrm{Cd}$, the concentration levels of most metals reached the first level according to the National Seawater Quality Standard of China (GB 3097-1997), indicating that the concentrations were within the range of clean water. Consequently, Cd was the main pollutant element in the seawater of Yalujiang Estuary.

In this study, the median grain size $(\mathrm{Mz})$ varied between $2.0 \varphi$ and $5.2 \varphi$, with a mean value of $3.0 \Phi$, indicating that the sediments of Yalujiang mainly comprised fine sand-sized components. The TOC ranged from $0.02 \%$ to $0.60 \%$, with an average of $0.22 \%$. The metal concentrations ( $\mathrm{mg} / \mathrm{kg}$ ) ranged from 0.008 to 0.184 (average 0.05 ) for $\mathrm{Hg}$, from 5.3 to 15.1 (average 9.37) for $\mathrm{Cu}$, from 26.0 to 53.8 (average 37.86) for $\mathrm{Zn}$, from 12.2 to 37.7 (average 24.3) for $\mathrm{Cr}$, from 0.05 to 0.41 (average 0.20 ) for $\mathrm{Cd}$, from 12.3 to 29.9 (average 17.95) for $\mathrm{Pb}$, and from 3.8 to 11.3 (average 6.36) for As (Table 2, Supplement Table S2).

A comparison of the metal concentrations in the sediments of Yalujiang Estuary and those in some typical estuaries in China is provided in Table 2. The mean contents of $\mathrm{Hg}, \mathrm{Cd}$ and As in Yalujiang Estuary were higher than their corresponding average values in the East China, while the contents of $\mathrm{Cu}, \mathrm{Zn}, \mathrm{Cr}$ and $\mathrm{Pb}$ were lower. The mean concentration of $\mathrm{Hg}$ in the study area was higher than that of other representative estuaries in China, including Liaohe Estuary (Li et al., 2007), Perl River Estuary (Zhou et al., 2004), Changjiang Estuary (Zhang et al., 2009), and Luanhe Estuary (Liu et al., 2016a, b). With regard to $\mathrm{Cu}, \mathrm{Zn}$, and $\mathrm{Cr}$, their contents in Yalujiang Estuary were lower than those in other representative coastal regions in China. In addition, with regard to the other three elements (i.e., $\mathrm{Cd}, \mathrm{Pb}$, and $\mathrm{As}$ ), their average contents were comparable to those in Liaohe Estuary and Luanhe Estuary. The concentration levels of all metals attained the first level according to the Chinese Marine Sediment Quality Standard Criteria (GB 186682002), indicating that the concentrations of metals in the study area were within the range of clean sediment.

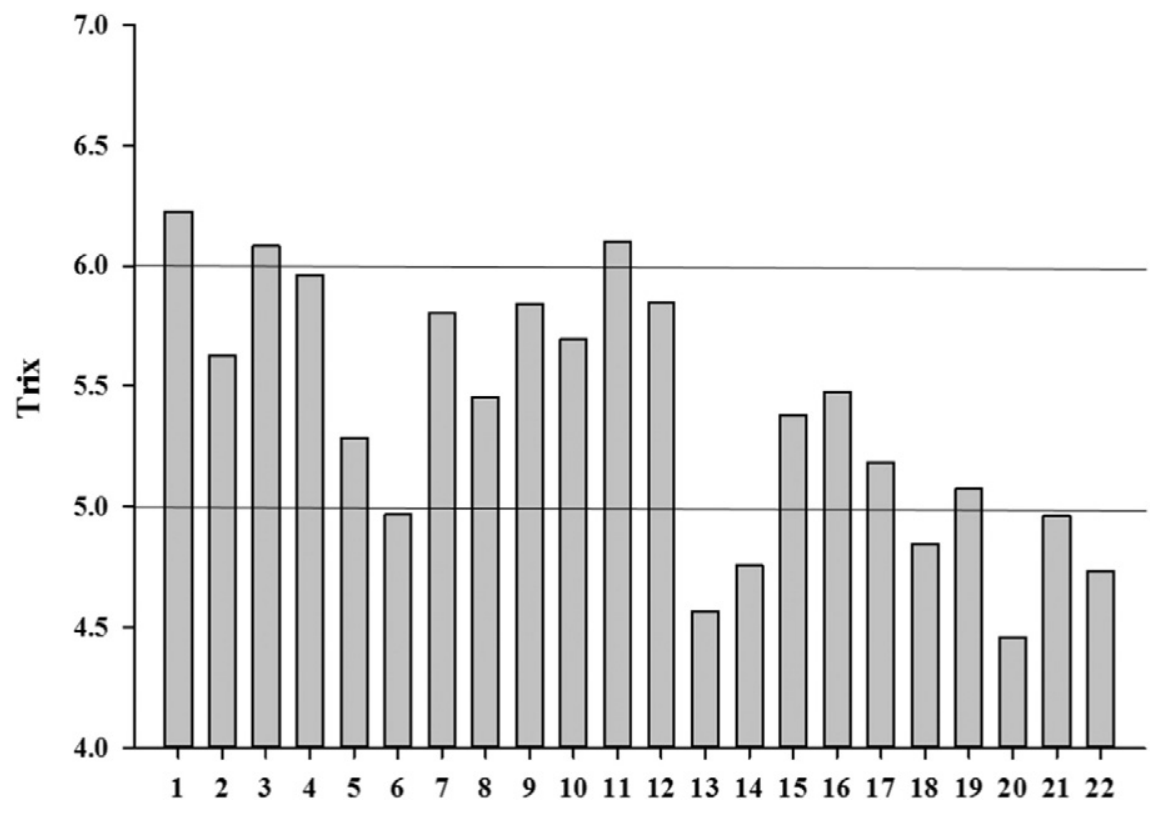

Fig. 2. The variations of the trophic index (TRIX) in Yalujiang Estuary. Moderate production: $4<$ TRIX $<5$; moderate and high production: $5<$ TRIX $<6$; high production: TRIX $>6$. 
Table 1

Comparison of dissolved heavy metal concentrations in the surface seawater of some typical area $(\mu \mathrm{g} / \mathrm{L})$.

\begin{tabular}{|c|c|c|c|c|c|c|c|c|}
\hline Region & $\mathrm{Cu}$ & $\mathrm{Zn}$ & $\mathrm{Cr}$ & $\mathrm{Hg}$ & $\mathrm{Cd}$ & $\mathrm{Pb}$ & As & Reference \\
\hline \multirow[t]{2}{*}{ Yalujiang Estuary } & $1.80-4.70$ & $9.20-19.60$ & $0.113-0.14$ & $0.006-0.049$ & $0.83-1.33$ & $0.40-1.80$ & $1.60-2.05$ & This study \\
\hline & 2.86 & 14.93 & 0.13 & 0.03 & 1.18 & 0.68 & 1.80 & \\
\hline Southern Yellow Sea & 1.12 & 3.44 & nd & 0.0086 & 0.053 & 0.30 & 1.66 & He et al. (2008) \\
\hline Jinzhou Bay & 3.06 & 11.87 & nd & 0.03 & 0.92 & 0.61 & 2.19 & Wang et al.(2012) \\
\hline Tianjin Bay & 2.54 & 26.9 & 0.40 & 0.04 & 0.12 & 7.18 & 1.26 & Meng et al. (2008) \\
\hline Dingzi Bay & 2.02 & 23.62 & 4.10 & 0.05 & 0.36 & 1.07 & 1.33 & Pan et al.(2014) \\
\hline The Pearl River Estuary & 1.64 & 13.54 & nd & nd & 0.12 & 1.61 & 2.55 & Zhang et al. (2013) \\
\hline Changjiang Estuary & 0.96 & 7.56 & 0.39 & nd & 0.06 & 0.68 & nd & Sun et al. (2009) \\
\hline SWQ-1 & 5 & 20 & 50 & 0.05 & 1 & 1 & 20 & AQSIQ (1997) \\
\hline SWQ-2 & 10 & 50 & 100 & 0.20 & 5 & 5 & 30 & AQSIQ (1997) \\
\hline
\end{tabular}

SWQ-1 and SWQ-2 are included in Chinese Sea Water Quality standard criteria (GB 3097-1997) issued by Administration of Quality Supervision, Inspection and Quarantine (AQSIQ). nd: no data.

Overall, the analyzed trace elements in the Yalujiang Estuary sediment generally showed similar distribution patterns (Fig. 3). In general, the sample sites with lower metal concentrations were located in the downstream regions, while the higher content sites were distributed near the mouth of the estuary. As and $\mathrm{Cr}$ exhibited similar distributions. These two elements presented high concentration levels in the western part of the study area, near the mouth of the Dayang River. These results suggested that the riverine input was an important source of metal pollution in this area. All metal elements (except As and $\mathrm{Cr}$ ) exhibited high concentration levels around sites S05 and S06 because these sites are located near the shipping channel, where wastewater is frequently discharged.

The Pearson correlation coefficients among the trace elements, TOC, sulfide, and $\mathrm{Mz}$ in the sediments are shown in Table 3. Significant positive correlations existed between TOC and $\mathrm{Mz}(r=0.732, P<0.01)$, indicating that the sediment grain size is the main factor influencing TOC accumulation. The significant correlation between $\mathrm{TOC}$ and $\mathrm{Cr}(\mathrm{r}=0.56$, $P<0.05)$ suggested that TOC might be a major influencing factor on the abundance of $\mathrm{Cr}$, which was obviously influenced by anthropogenic sources. $\mathrm{Cu}$ showed significant correlations with $\mathrm{Zn}(\mathrm{r}=0.78$, $P<0.01), \mathrm{Cr}(\mathrm{r}=0.53, P<0.05)$, and $\mathrm{Cd}(\mathrm{r}=0.48, P<0.05)$, indicating that these metals might have a common natural or anthropogenic source. The poor correlation between $\mathrm{Mz}$ and heavy metals suggested that $\mathrm{Mz}$ was not the main factor controlling the concentrations of metals.

The contamination factor $(C F)$ and pollution load index $(P L I)$ were used to assess the degree of anthropogenic metal contamination. The $C F$ is calculated as the ratio of the measured concentration in the sediment to the background value, that is, $C F=\mathrm{Me}_{\text {sample }} / \mathrm{Me}_{\text {baseline }}$.

$C F$ is classified into four levels: low degree $(C F<1)$, moderate level $(1 \leq C F<3)$, considerable degree $(3 \leq C F<6)$, and high degree $(C F \geq 6)$ (Loska et al., 1997). The $C F$ values of heavy metal in this study varied as follows: 0.72-6.31 (mean of 3.07) for Cd, 0.32-7.24 (mean of 2.19) for $\mathrm{Hg}, 0.61-1.50$ (mean of 0.90 ) for $\mathrm{Pb}, 0.49-1.47$ (mean of 0.83 ) for As, $0.35-1.00$ (mean of 0.62 ) for $\mathrm{Cu}, 0.40-0.83$ (mean of 0.58 ) for $\mathrm{Zn}$, and $0.20-0.63$ (mean of 0.41 ) for $\mathrm{Cr}$ (Fig. 4A). These results suggested that $\mathrm{Cd}$ was the foremost contaminant in the sediment of Yalujiang Estuary, with the $C F$ values of all sample sites $>1$ (Fig. 5). The $C F$ values of the seven trace elements were found to be in the following order: $\mathrm{Cd}>\mathrm{Hg}>\mathrm{Pb}>\mathrm{As}>\mathrm{Cu}>\mathrm{Zn}>\mathrm{Cr}$. The CF values of the other six elements indicated that S11, S13, S14, S15, S16, S17, S18, and S20 were the cleanest sites as their $C F$ values were $<1$. By contrast, the sediments collected at $\mathrm{S} 1$ and $\mathrm{S} 8$ were considerably polluted with $\mathrm{Cd}$ and $\mathrm{Hg}$, with $C F$ values of $>3$.

The PLI was applied to compare the integrated pollution status at different sample sites because heavy metals always occur in sediments as complex mixtures with great variation: $P L I=\left(C_{1} \times C F_{2} \times C F_{3} \times \ldots \times-\right.$ $\left(F_{n}\right)^{1 / n}$.

The PLI is determined as the $n$th root of the multiplications of $C F$. $P L I>1$ indicates a polluted condition, whereas $P L I<1$ indicates no metal pollution (Tomlinson et al., 1980). In the study area, the PLI values ranged from 0.44 to 1.27 , with an average of 0.86 (Fig. 6). Among all sample sites, 7 of 19 values were $>1$, indicating that $36.8 \%$ of the sites were metal contaminated to some extent. Furthermore, the contaminated sites were located near the mouth of the estuary. This finding is similar to that observed from the $C F$ index.

The geoaccumulation index $\left(I_{\text {geo }}\right)$ is another parameter to assess the metal contamination in sediments with a corresponding natural background level as a reference (Müller, 1969):

$$
I_{\text {geo }}=\log _{2}\left(\frac{C_{n}}{1.5 B_{n}}\right) \text {, }
$$

where $C_{n}$ is the concentration of a metal $(n)$ in the sample and $B_{n}$ is the geochemical background concentration of the metal $(n)$. The factor (1.5) is a background matrix correction factor attributed to lithogenic effects (Müller, 1979). $I_{\text {geo }}$ is classified into seven levels: unpolluted $\left(I_{\text {geo }} \leq 0\right)$, unpolluted to moderately polluted $\left(0<I_{\text {geo }} \leq 1\right)$, moderately polluted $\left(1<I_{g e o} \leq 2\right)$, moderately to strongly polluted $\left(2<I_{g e o} \leq 3\right)$, strongly polluted $\left(3<I_{\text {geo }} \leq 4\right)$, strongly to extremely polluted $\left(4<I_{g e o} \leq 5\right)$, and extremely polluted $\left(I_{g e o}>5\right)$. The $I_{g e o}$ values of the surface sediments from the Yalujiang Estuary decreased in the following

Table 2

Comparison of heavy metal concentrations in the surface sediments of the Yalujiang Estuary and other representative coastal regions in China (mg/kg).

\begin{tabular}{|c|c|c|c|c|c|c|c|c|}
\hline Locations & $\mathrm{Cu}$ & $\mathrm{Zn}$ & $\mathrm{Cr}$ & $\mathrm{Hg}$ & $\mathrm{Cd}$ & $\mathrm{Pb}$ & As & References \\
\hline \multirow[t]{2}{*}{ Yalujiang Estuary } & $5.3-15.1$ & $26.0-53.8$ & $12.2-37.7$ & $0.008-0.181$ & $0.05-0.41$ & $12.3-29.9$ & $3.8-11.3$ & This study \\
\hline & 9.37 & 37.86 & 24.3 & 0.05 & 0.20 & 17.95 & 6.36 & \\
\hline Liaohe Estuary & 14.94 & nd & 49.0 & 0.039 & 0.175 & 12.86 & 6.54 & Liu et al. $(2016 a, b)$ \\
\hline Perl River Estuary & 46.2 & 150.1 & 89 & nd & nd & 59.3 & nd & Zhou et al. (2004) \\
\hline Changjiang Estuary & 30.7 & 94.3 & 78.9 & nd & 0.26 & 27.3 & nd & Zhang et al. (2009) \\
\hline Luanhe Estuary & 18.76 & 44.63 & 41.14 & 0.02 & 0.09 & 30.98 & 7.21 & Liu et al. (2016a, b) \\
\hline Southern Bohai Bay & 22.7 & 71.7 & 33.5 & nd & 0.14 & 21.7 & nd & Hu et al. (2013) \\
\hline Laizhou Bay & 22 & 60.4 & 60 & nd & 0.12 & 21.9 & 12.7 & Xu et al. (2015) \\
\hline Average upper crust of East China & 27 & 66 & 99 & 0.0094 & 0.091 & 15 & 5.6 & Gao et al. (1998) \\
\hline MSQ-1 & 35 & 150 & 80 & 0.2 & 0.5 & 60 & 20 & AQSIQ (2002) \\
\hline
\end{tabular}

MSQ-1 is included in Chinese Marine Sediment Quality Standard Criteria (GB 18668-2002) issued by Administration of Quality Supervision, Inspection and Quarantine (AQSIQ). nd: no data. 

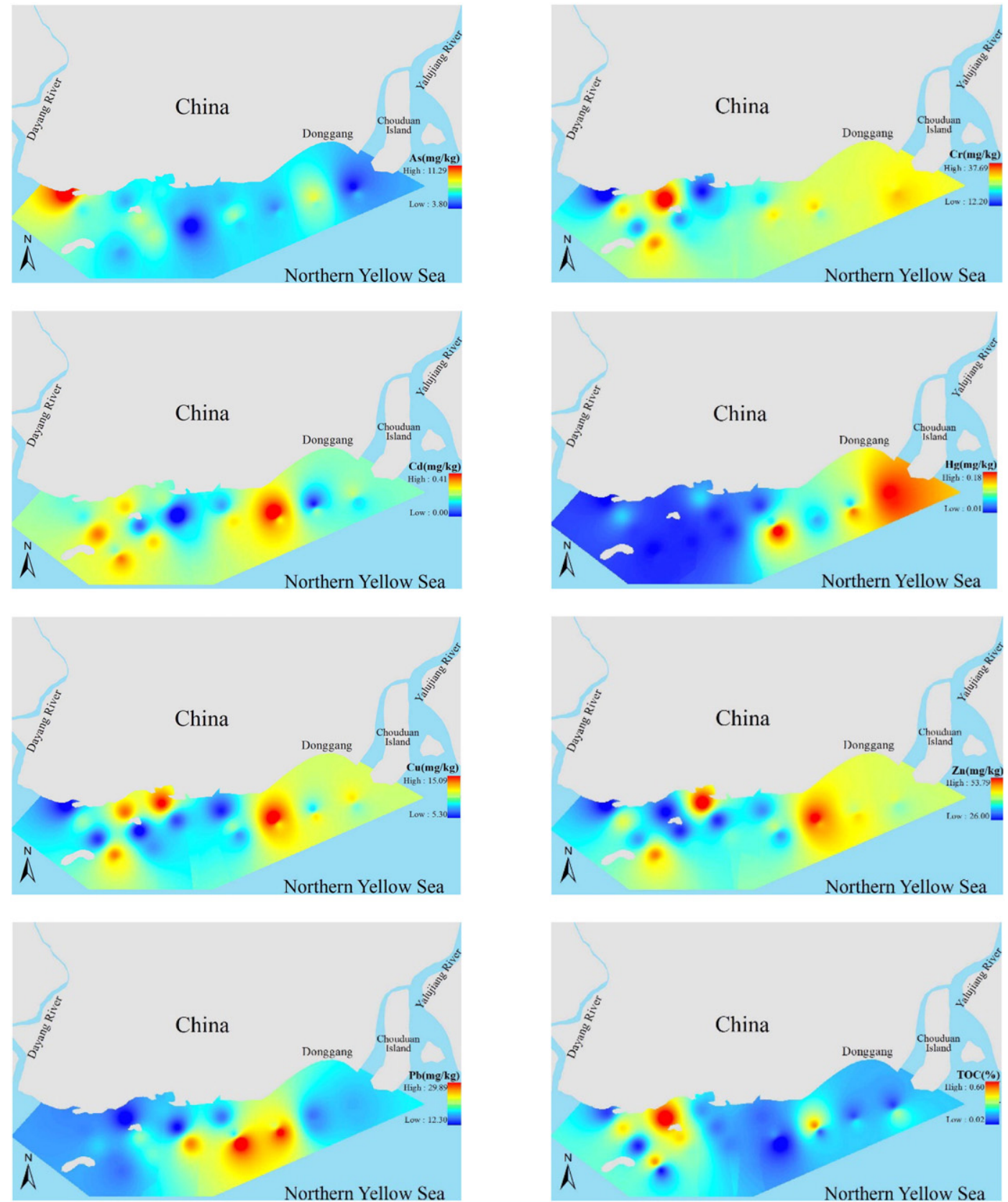

Fig. 3. Spatial distribution of heavy metals ( $\mathrm{As}, \mathrm{Cr}, \mathrm{Cd}, \mathrm{Hg}, \mathrm{Cu}, \mathrm{Pb}$ and $\mathrm{Zn}, \mathrm{mg} / \mathrm{kg}$ ) and total organic carbon (TOC, \%) of surface sediments in Yalujiang Estuary.

Table 3

Pearson's correlation matrix for the analyzed parameters in the sediments of Yalujiang Estuary.

\begin{tabular}{|c|c|c|c|c|c|c|c|c|c|c|}
\hline & $\mathrm{Cu}$ & $\mathrm{Pb}$ & $\mathrm{Zn}$ & $\mathrm{Cr}$ & $\mathrm{Cd}$ & As & $\mathrm{Hg}$ & TOC & Sulfide & $\mathrm{Mz}$ \\
\hline $\mathrm{Cu}$ & 1 & & & & & & & & & \\
\hline $\mathrm{Pb}$ & -0.019 & 1 & & & & & & & & \\
\hline $\mathrm{Zn}$ & $0.78^{* *}$ & 0.14 & 1 & & & & & & & \\
\hline $\mathrm{Cr}$ & $0.53^{*}$ & -0.13 & 0.18 & 1 & & & & & & \\
\hline $\mathrm{Cd}$ & $0.48^{*}$ & 0.17 & 0.28 & 0.21 & 1 & & & & & \\
\hline As & -0.42 & -0.21 & -0.31 & $-0.48^{*}$ & -0.23 & 1 & & & & \\
\hline $\mathrm{Hg}$ & 0.19 & 0.29 & 0.19 & 0.25 & -0.023 & -0.26 & 1 & & & \\
\hline TOC & 0.42 & -0.29 & 0.072 & $0.56^{*}$ & 0.10 & -0.10 & -0.21 & 1 & & \\
\hline Sulfide & $0.49^{*}$ & -0.082 & $0.45^{*}$ & 0.34 & 0.18 & -0.095 & $0.45^{*}$ & 0.36 & 1 & \\
\hline $\mathrm{Mz}$ & $0.636^{* *}$ & -0.229 & 0.286 & $0.560^{*}$ & 0.405 & -0.132 & -0.322 & $0.732^{* *}$ & 0.281 & 1 \\
\hline
\end{tabular}

* Correlation is significant at the 0.05 level (two-tailed).

** Correlation is significant at the 0.01 level (two-tailed). 

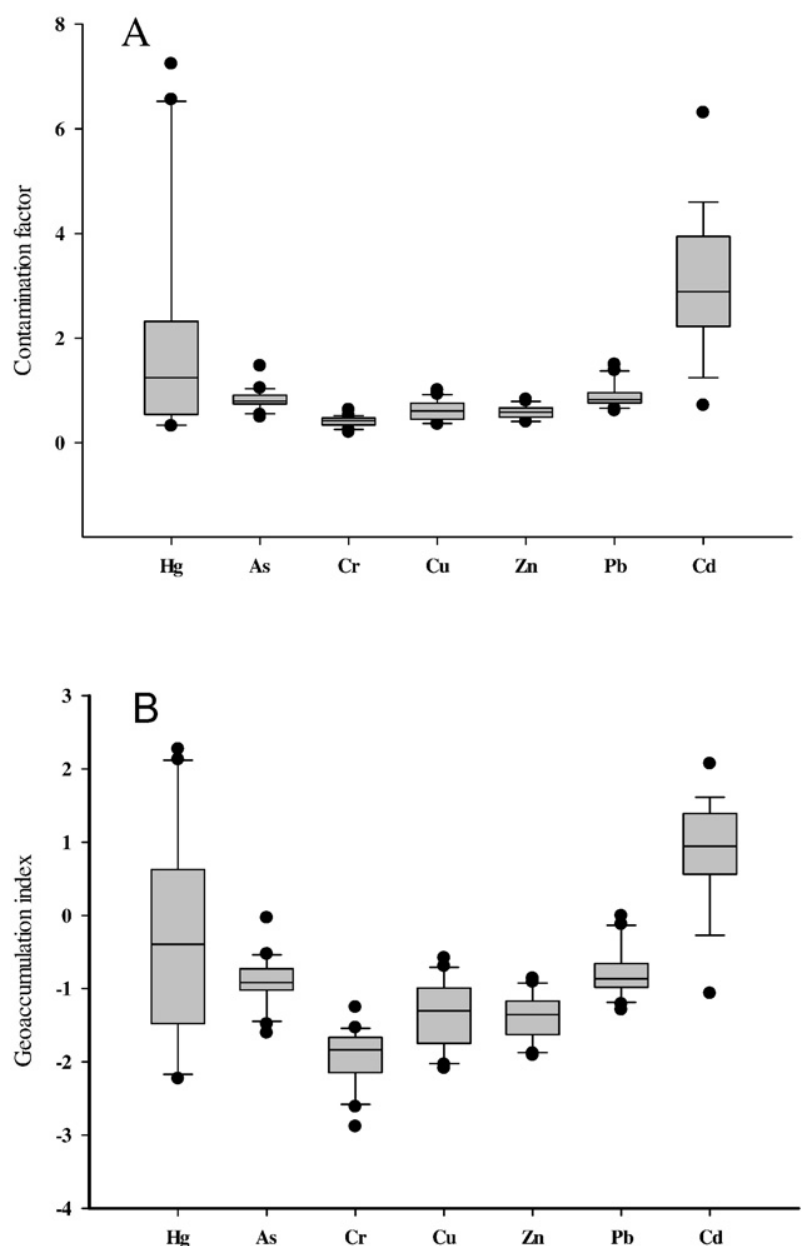

Fig. 4. Box-and-whisker plots for of heavy metals in the surface sediments of Yalujiang Estuary. A: enrichment factor (CF); B: Geoaccumulation index $\left(I_{\text {geo }}\right)$.

order: -1.07 to 2.07 (average 0.88 ) for $\mathrm{Cd},-2.23$ to 2.27 (average 0.18 ) for $\mathrm{Hg},-1.29$ to 0 (average -0.78 ) for $\mathrm{Pb},-1.60$ to -0.03 (average -0.90 ) for $\mathrm{As},-2.09$ to -0.58 (average -1.33 ) for $\mathrm{Cu},-1.91$ to -0.86 (average -1.40 ) for $\mathrm{Zn}$, and -2.88 to -1.25 (average -1.93 ) for Cr (Fig. 4B). On the basis of the Müller scale (Müller, 1979), except $\mathrm{Cd}$, the $I_{\text {geo }}$ values indicated no metal pollution in Yalujiang Estuary as a whole. However, minimal deviations were observed across metals and sample sites. The average $I_{\text {geo }}$ value of $\mathrm{Cd}$ was between 0 and 1 , suggesting that slight to moderate Cd pollution occurred in Yalujiang Estuary. As shown in Fig. 7, the $I_{g e o}$ values of $\mathrm{As}, \mathrm{Cr}, \mathrm{Cu}, \mathrm{Zn}$, and $\mathrm{Pb}$ in all the sample sites were categorized as class 0 , indicating that the sediments

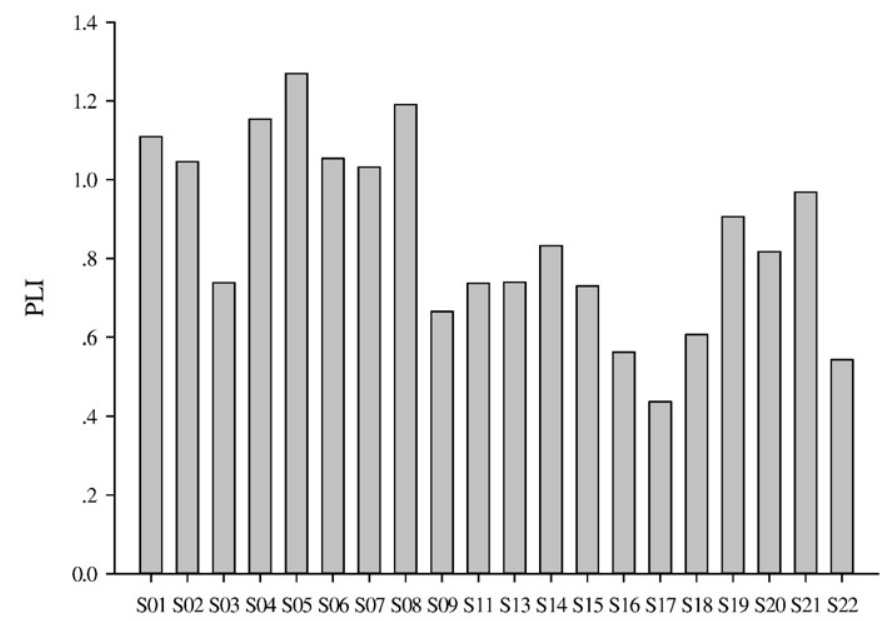

Site

Fig. 6. The spatial variations of pollution load index (PLI) of the heavy metals in the sediment of Yalujiang Estuary.

in all the sites were unpolluted by these metals. Six sites and eight sites were unpolluted to moderately polluted, one site and eight sites were moderately polluted, and three sites and one site were moderately to strongly polluted with $\mathrm{Hg}$ and $\mathrm{Cd}$, respectively.

CA was used to group the similar sampling sites and determine the specific areas of contamination. Hierarchical CA was performed on the normalized data set using Ward's method (Ward, 1963) based on AU/ BP values. Spatial CA produced a dendrogram, which clustered two clades (Fig. 8). Cluster 1 contained 7 sites in the downstream regions, which corresponded to the low-contamination sites. Cluster 2 comprised the other 13 sites in the upper estuary, which corresponded to the high-contamination sites. The cluster classifications varied with the significance level because the sites in these clusters had similar characteristic features and anthropogenic/natural background source types. These results indicated that the geographical regions presented different degrees of contamination in Yalujiang Estuary, suggesting that anthropogenic activities with wastewater discharge were possible significant sources of pollution.

Based on Ward's normalized data, CA was employed to determine the relationships among the analyzed trace elements and their possible sources. The rendered dendrogram (Fig. 9) produced two clusters. Cluster 1 included $\mathrm{Cr}, \mathrm{Cd}, \mathrm{Cu}$, and $\mathrm{Zn}$, which mainly represented the riverine input and coastal industrial discharge. The upstream region of Yalujiang River has the largest copper reserves in Asia, and this region has been heavily mined since the nineteenth century (Gao et al., 2008). The $\mathrm{Cu}$ and $\mathrm{Zn}$ accumulation in the sediment of the estuary might have been derived from the discharges of the copper mine plant. By contrast, the

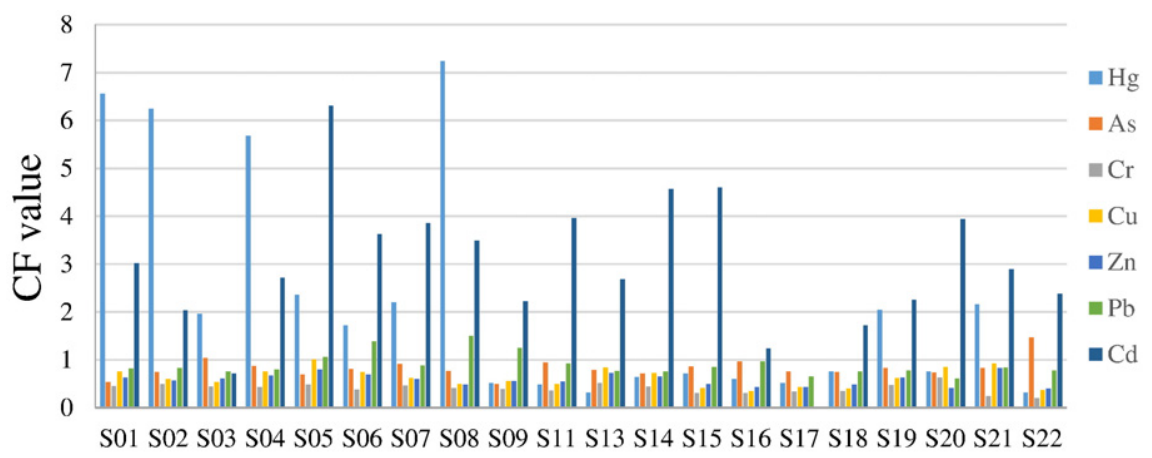

Site

Fig. 5. The spatial variations of the contamination factor $(C F)$ of seven trace elements in the sediment of Yalujiang Estuary. 


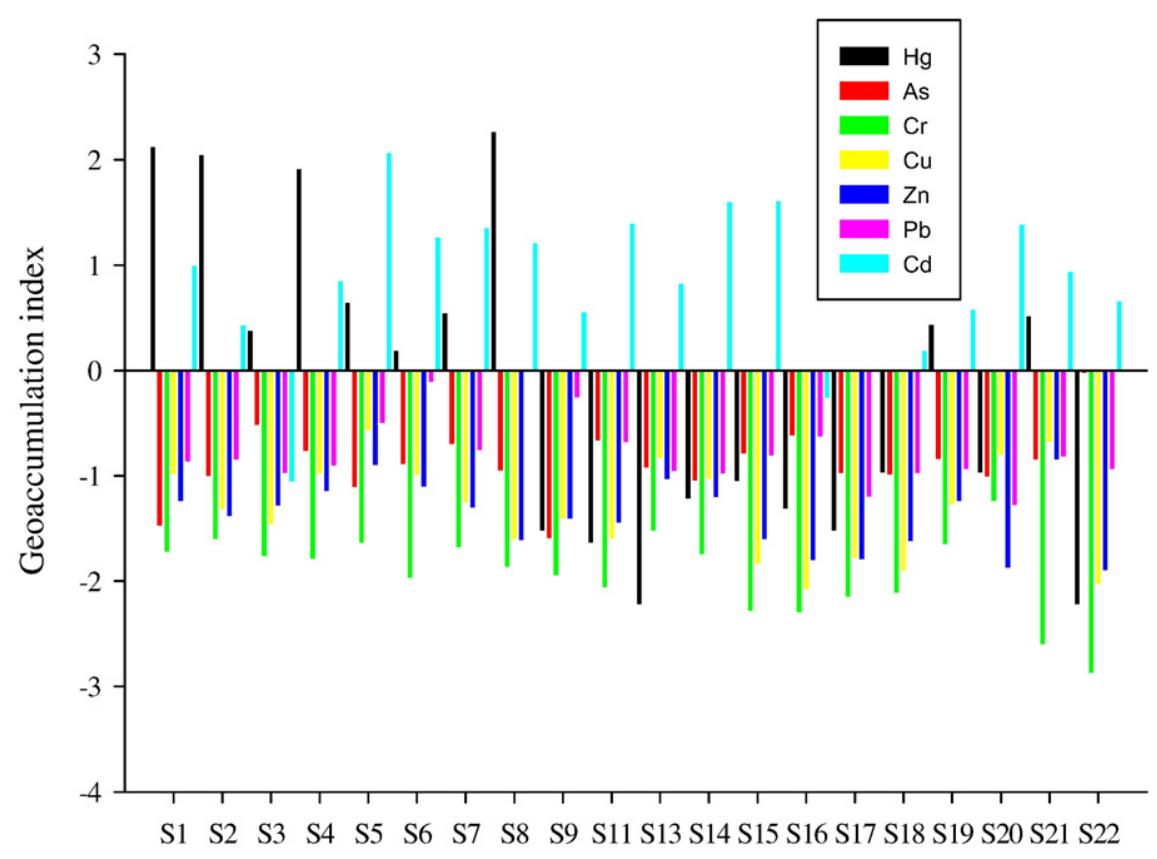

Site

Fig. 7. Spatial variations of the geoaccumulation index $\left(I_{g e o}\right)$ of seven trace elements in Yalujiang Estuary.

environmental occurrence of $\mathrm{Cd}$ can be attributed to its considerable usage in electroplating, pigment production, and the manufacture of plastic stabilizers and batteries (Eisler, 2007). Some industrial enterprises are concentrated in the cities of Dandong and Donggang, including automobile, papermaking, printing, and textile companies. Consequently, substantial amounts of industrial effluents have been discharged into the sea, and these effluents could have contributed to the accumulation of $\mathrm{Cd}$ in the sediment of the Yalujiang Estuary. Cluster 2 contained $\mathrm{As}, \mathrm{Hg}$, and $\mathrm{Pb}$, which are primary sources of metal contamination from the precipitation of aerosols (Liu et al., 2016a, b). Shipping activities with vehicle emissions and oil combustion could be other sources of metal contamination in this region.

In conclusion, this field study assessed the levels of the nutrients and seven trace elements $(\mathrm{Hg}, \mathrm{As}, \mathrm{Pb}, \mathrm{Cu}, \mathrm{Cd}, \mathrm{Cr}$, and $\mathrm{Zn}$ ) in both the seawater and sediment of Yalujiang Estuary. The results showed that the overall condition of the study area was eutrophic, with the eutrophication risk of the nutrients ranging from moderate to high production. With the exception of $\mathrm{Cd}$, the concentration levels of most metals attained

\section{Cluster dendrogram with AU/BP values (\%)}

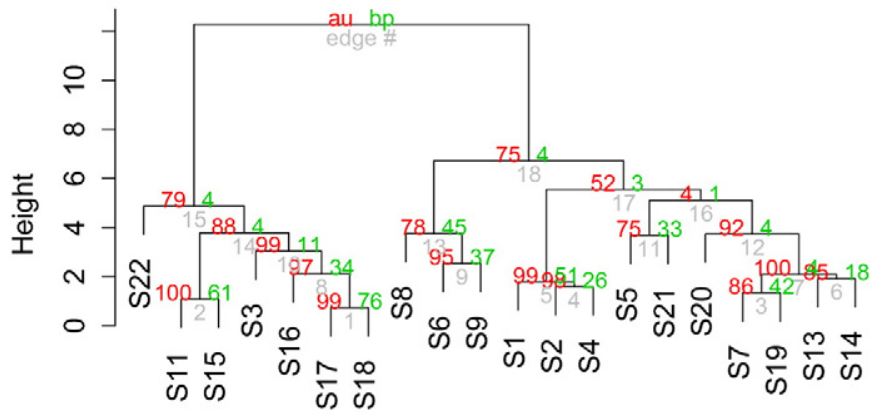

Distance: euclidean Cluster method: ward.D

Fig. 8. Dendrogram showing clustering of sediment sample site in the Yalujiang Estuary. the first level according to the National Seawater Quality Standard of China (GB 3097-1997), indicating that the concentrations were within the range of clean water. High concentrations of nutrients and heavy metals in seawater samples were located at the mouth of Yalujiang Estuary; this finding indicated that riverine inputs were possible significant sources of pollution. Sediment pollution assessment was undertaken using $C F$ and $I_{\text {geo }}$, which indicated elevated $\mathrm{Cd}$ and $\mathrm{Hg}$ concentrations in the region. The sources of $\mathrm{Cu}, \mathrm{Cd}, \mathrm{Cr}$, and $\mathrm{Zn}$ were mainly derived from copper mine and coastal industrial effluents, whereas $\mathrm{Pb}, \mathrm{Hg}$, and As were mainly from vehicle emissions and oil combustion.

\section{Acknowledgments}

This study was supported by National Natural Science Foundation of China (31572595, 41676115), National Marine Public Welfare Research Project (201305030) and grant from the State Oceanic Administration of China (GASI-03-01-02-05).

\section{Cluster dendrogram with AU/BP values (\%)}

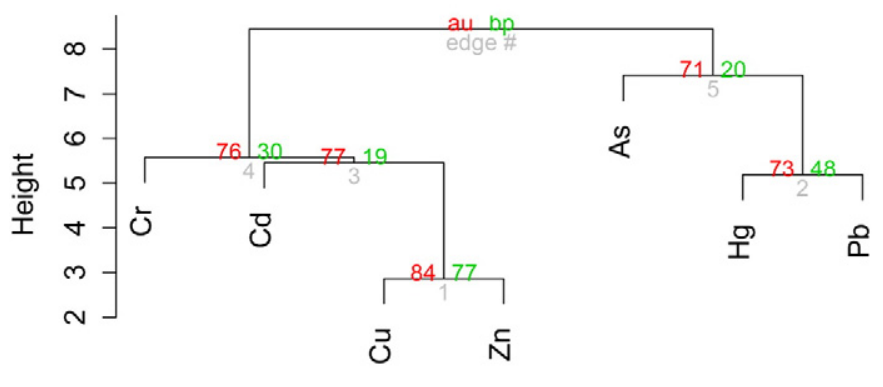

Distance: euclidean Cluster method: ward.D

Fig. 9. Dendrogram showing clustering of the analyzed trace elements in sediment samples. 


\section{Appendix A. Supplementary data}

Supplementary data to this article can be found online at http://dx. doi.org/10.1016/j.marpolbul.2017.01.069.

\section{References}

AQSIQ 1997. Sea Water Quality Standard (GB 3097-1997). Standards Press of China, Beijing (Administration of quality supervision, inspection and quarantine of the People's Republic of China).

AQSIQ 2002. Marine Sediment Quality of China (GB 18668-2002). Standards Press of China, Beijing (Administration of quality supervision, inspection and quarantine of the People's Republic of China).

Chapman, P.M., Wang, F., 2001. Assessing sediment contamination in estuaries. Environ. Toxicol. Chem. 20, 3-22.

Cheng, Y., Liu, Y., Li, F.X., Gao, J.H., Liu, J.W., Zhang, L., 2011. Comparative study of enrichment features and potential ecological risks of heavy metals in sediments of the Yalu River Estuary and its adjacent shallow sea area. Res. Environ. Sci. 24, 516-525.

Eisler, R., 2007. Zinc. In: Eisler, R. (Ed.), Eisler's Encyclopedia of Environmentally Hazardous Priority Chemicals. Elsevier Science, Oxford, UK, pp. 841-843.

Gan, H.Y., Lin, J.Q., Liang, K., Xia, Z., 2013. Selected trace metals (As, Cd and Hg) distribution and contamination in the coastal wetland sediment of the northern Beibu Gulf, South China Sea. Mar. Pollut. Bull. 66, 252-258.

Gao, S., Luo, T.C., Zhang, B.R., Zhang, H.F., Han, Y.W., Zhao, Z.D., Hu, Y.K., 1998. Chemical composition of the continental crust as revealed by studies in East China. Geochim. Cosmochim. Acta 62 (11), 1959-1975.

Gao, J.H., Li, J., Wang, Z.Y., Wang, Y.P., Bai, F.L., Cheng, Y., 2008. Heavy metal distribution and their influence factors in sediments of Yalu River Estuary and its adjacent sea area. Geochimica 37, 430-438 (Chinese edition with English abstract).

Grasshoff, K., Ehrhardt, M., Kremling, K., 1983. Methods of Seawater Analysis, Second Revised and Extended ed. Verlag Chemie, Kiel, p. 419

He, Z.P., Song, J.M., Zhang, N.X., Xu, Y.Y., Zhang, G.X., Zhang, P., 2008. Variation characteristics and controlling factors of heavy metals in the South Yellow Sea surface seawaters. Environ. Sci. 29, 1153-1162 (Chinese edition with English abstract).

Hill, N.A., Simpson, S.L., Johnston, E.L., 2013. Beyond the bed: effects of metal contamination on recruitment to bedded sediments and overlying substrata. Environ. Pollut. 173, 182-191.

Hu, B.Q., Li, G.G., Li, J., Bi, J.Q., Zhao, J.T., Bu, R.Y., 2013. Spatial distribution and ecotoxicological risk assessment of heavy metals in surface sediments of the southern Bohai Bay, China. Environ. Sci. Pollut. Res. 20, 4099-4110.

Ip, C.C.M., Li, X.D., Zhang, G., Wai, O.W.H., Li, Y.S., 2007. Trace metal distribution in sediments of the Pearl River Estuary and the surrounding coastal area, South China. Environ. Pollut. 147, 311-323.

Li, H.J., Ye, S., Ye, J.Q., Fan, J.F., Gao, M.L., Guo, H., 2007. Baseline survey of sediments and marine organisms in Liaohe Estuary: heavy metals, polychlorinated biphenyls and organochlorine pesticides. Mar. Pollut. Bull. 114, 555-563.

Liu, R.M., Men, C., Liu, Y.Y., Yu, W.W., Xu, F., Shen, Z.Y., 2016a. Spatial distribution and pollution evaluation of heavy metals in Yangtze estuary sediment. Mar. Pollut. Bull. 110, 564-571.

Liu, J.Q., Yin, P., Chen, B., Gao, F., Song, H.Y., Li, M.N., 2016b. Distribution and contamination assessment of heavy metals in surface sediments of the Luanhe River Estuary, northwest of the Bohai Sea. Mar. Pollut. Bull. 109, 633-639.

Loska, K., Cebula, J., Pelczar, J., et al., 1997. Use of enrichment, and contamination factors together with geoaccumulation indexes to evaluate the content of $\mathrm{Cd}, \mathrm{Cu}$, and $\mathrm{Ni}$ in the Rybnik water reservoir in Poland. Water Air Soil Pollut. 93, 347-365.
Lotze, H.K., Lenihan, H.S., Bourque, B.J., Bradbury, R.H., Cooke, R.G., Kay, M.C., et al., 2006. Depletion, degradation, and recovery potential of estuaries and coastal seas. Science 312, 1806-1809.

Meng, W., Qin, Y.W., Zheng, B.H., Zhang, L., 2008. Heavy metal pollution in Tianjin Bohai bay, China. J. Environ. Sci. 20 (7), 814-819.

Müller, G., 1969. Index of geoaccumulation in the sediments of the Rhine River. Geol. J. 2 $108-118$.

Müller, G., 1979. Schwermetalle in den sedimenten des Rheins-Veranderungen seitt. Umschau 79, 778-783.

Pan, K., Wang, W.X., 2012. Trace metal contamination in estuarine and coastal environments in China. Sci. Total Environ. 421, 3-16.

Pan, J.J., Pan, J.F., Wang, M., 2014. Trace elements distribution and ecological risk assessment of seawater and sediments from Dingzi Bay, Shandong Peninsula, North China. Mar. Pollut. Bull. 89, 427-434.

Sun, W.P. Pan, J.M., Lu, H.Y. Xue, B. 2009. Distribution of dissolved trace metals in summer and winter of 2006 in Changjiang River Estuary and Hangzhouwan Bay. J. Mar. Sci. 27, 37-43 (Chinese edition with English abstract).

Suzuki, R., Shimodaira, H., 2006. Pvclust: an R package for assessing the uncertainty in hierarchical clustering. Bioinformatics 22 (12), 1540-1542.

Tomlinson, D.L., Wilson, J.G., Harris, C.R., Jeffrey, D.W., 1980. Problems in the assessment of heavy-metal levels in estuaries and the formation of a pollution index. Helgoländer Meeresun. 33, 566-575.

Valdés, J., Vargas, G., Sifeddine, A., Ortlieb, L., Guinez, M., 2005. Distribution and enrichment evaluation of heavy metals in Mejillones Bay (23 S), Northern Chile: geochemical and statistical approach. Mar. Pollut. Bull. 50 (12), 1558-1568.

Vollenweider, R.A., Giovanardi, F., Montanari, G., Rinaldi, A., 1998. Characterization of the trophic conditions of marine coastal waters with special reference to the NW Adriatic Sea: proposal for a trophic scale, turbidity and generalized water quality index. Environmetrics 9, 329-357.

Wang, J., Liu, R.H., Yu, P., Tang, A.K., Xu, L.Y., Wang, J.Y., 2012. Study on the pollution characteristics of heavy metals in seawater of Jinzhou Bay. Proced. Environ. Sci. 13 1507-1516.

Ward, J., 1963. Hierarchical grouping to optimize an objective function. J. Am. Stat. Assoc $58,236-244$.

Wu, Y., Zhang, J., Zhu, Z.J., 2003. Polycyclic aromatic hydrocarbons in the sediments of the Yalujiang Estuary, North China. Mar. Pollut. Bull. 46 (5), 619-625.

Xu, G., Liu, J., Pei, S.F., et al., 2015. Sediment properties and trace metal pollution assessment in surface sediments of the Laizhou Bay, China. Environ. Sci. Pollut. Res. 22, 11634-11647.

Yang, Y.Q., Chen, F.R., Zhang, L., Liu, J.S., Wu, S.J., Kang, M.L., 2012. Comprehensive assessment of heavy metal contamination in sediment of the Pearl River Estuary and adjacent shelf. Mar. Pollut. Bull. 64, 1947-1955.

Zhang, W.G., Feng, H., Chang, J.N., Qu, J.G., Xie, H.X., Yu, L.Z., 2009. Heavy metal contamination in surface sediments of Yangtze River intertidal zone: an assessment from different indexes. Environ. Pollut. 157, 1533-1543.

Zhang, G.S., Liu, D.Y., Wu, H.F., Chen, L.L., Han, Q.Y., 2012. Heavy metal contamination in the marine organisms in Yantai coast, northern Yellow Sea of China. Ecotoxicology 21 (6), 1726-1733.

Zhang, D.W., Zhang, X., Tian, L., Ye, F., Huang, X.P., et al., 2013. Seasonal and spatial dynamics of trace elements in water and sediment from Pearl River Estuary, South China. Environ.Earth Sci. 68, 1053-1063.

Zhou, H.Y., Peng, X.T., Pan, J.M., 2004. Distribution, source and enrichment of some chemical elements in sediments of the Pearl River Estuary, China. Cont. Shelf Res. 24, 1857-1875. 